1(*)Faizetul Ukhrawiyah ${ }^{2}$ Dian Fajariyah Damayanti 1 Universitas Islam Negeri Sunan Kalijaga, Yogyakarta 2Universitas Islam Malang

(*)faizahukhrawiyah@gmail.com

\section{The Implementation of Audiolingual Methods on Ta'diyah Salam Material}

DOI: 10.18196/mht.v3i2.10955

\begin{abstract}
The purpose of this study was to find out how the Implementation of the Audiolingual method in Ta'diyah Salam material students of VII MTS class Darussalam Al-Qurani Islamic Boarding School Indramayu, what are the obstacles faced by teachers in applying the method and how the efforts made in overcoming these obstacles. The method used is a descriptive qualitative method with data collection techniques such as observation, interviews, and documentation. The results of the study found that the Audiolingual method used in the ta'diyah salam material uses the technique of dialog memorization, backward build up, and repetition drill. The obstacles faced by teachers in using the method include the limited time available with a well-implemented drilling system, the conditions of students who are new to Arabic, as well as the fatigue and boredom experienced by students when learning takes place. However, of the many obstacles encountered, the teacher continues to strive to be able to overcome these obstacles by organizing the best possible time so that learning can run well, conveying conversation texts as clearly as possible to students, and providing learning media that are interesting for students so that they don't get bored quickly and tired.
\end{abstract}

Keywords: Audiolingual; Ta'diyah salam; Implementation

\title{
Abstrak
}

Tujuan dari penelitian ini adalah untuk mengetahui bagaimana penerapan metode Audiolingual pada materi ta'diyah salam pada siswa kelas VII MTS Pondok Pesantren Darussalam Al-Qurani Indramayu, apa saja kendala yang dihadapi guru dalam menerapkan metode tersebut serta bagaimana upaya yang dilakukan dalam mengatasi kendala tersebut. Metode yang digunakan adalah metode kualitatif deskriptif dengan teknik pengumpulan data berupa observasi, wawancara, dan dokumentasi. Dari hasil penelitian ditemukan bahwasanya metode Audiolingual yang digunakan pada materi 
ta'diyah salam menggunakan teknik dialog memorization, backward build up, dan repetition drill. Adapun kendala yang dihadapi guru dalam menggunakan metode tersebut meliputi keterbatasan waktu yang ada dengan sistem drilling yang diterapkan, kondisi siswa yang baru mengenal bahasa arab, serta rasa capek dan bosan yang dialami oleh siswa ketika pembelajaran berlangsung. Akan tetapi, dari sekian banyak kendala yang dihadapi, guru terus berupaya untuk dapat mengatasi kendala-kendala tersebut dengan mengatur waktu sebaik mungkin sehingga pembelajaran dapat berjalan dengan baik, menyampaikan teks percakapan dengan sejelas mungkin kepada siswa, serta memberikan media pembelajaran yang menarik bagi siswa agar mereka tidak cepat merasa bosan dan capek.

Kata Kunci: Audiolingual; Ta'diyah Salam; Implementasi

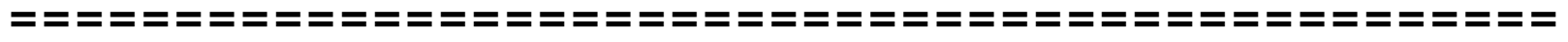

\section{INTRODUCTION}

The position of language as a means of communication between human beings has a very important role in life. Through language we can understand the intentions, ideas, and feelings of someone contained in it. Language is a means of understanding and explaining an existing reality, and without language life would be meaningless.

Arabic is one of the world's languages that continues to grow and develop in every aspect (Rikabi 1996, 18). Arabic as the language of Muslims occupies an important position, especially in Indonesia. This is not only because most of Indonesia's population is Moslem and uses Arabic in every worship performed, such as prayer, remembrance, reading the Koran, and so on, but more than that, Arabic is also used as a language of instruction in learning science. Islamic science throughout the world, as well as in Indonesia.

Learning Arabic is widely used in Indonesian educational institutions. They use Arabic as a daily language, both in learning activities and outside learning activities. The use of Arabic is intended to create an effective and conducive language environment.

There are several concerns in achieving the success of Arabic learning, especially the suitability of the methods used to support success in achieving learning objectives. The mismatch of methods in learning Arabic is one of the obstacles that causes the gap 
between expectations and reality in learning Arabic, because the method is central to the success of language teaching (B. Kumaravadivelu 2006, 83).

There are various methods of teaching in Arabic. There are at least five classical methods that still exist in various formal institutions: a) The Grammar Method of Tarjemah (Tariqoh Al-Qawa'id wa Al-Tarjamah), b) The Method of Reading (Thoriqoh AlQiro'ah), c) Direct Method (At-Tariqoh Al-Mubasyiroh), d) Audiolingual Method (AtTariqoh Al-Sam'iyyah Al-Syafahiyyah), and e) Electrical Method (Zaenuddin et al 2005, 37). The Implementation of these methods is adjusted to the educational approach adopted and the learning objectives to be achieved.

According to M. Ngalim Purwanto in his book "Theoretical and Practical Education", that:

"From many methods, the Audiolingual Method is one method that can be applied to Arabic Language students, and it is accordance with the convergence education approach and in line with Ki Hajar Dewantara's educational theory" Tut Wuri (following from behind) Handayani (encouraging or motivating) "Which is generally used as a basis in the selection of learning methods in Indonesia" (Purwanto 2000, 60-62).

In addition, the Audiolingual method is also in accordance with a variety of student learning styles both audio, visual and kinesthetic, because this method combines the innate talents of students in the form of hearing (audio), seeing / reading text (visual), as well as involving students in language experience (kinesthetic) (Hanani 2016, 247).

Audiolingual method is a method that is often used in teaching speaking skills (Maharah al-kalam) especially for beginner classes, such as Grade VII students of the AlQurani Islamic Boarding School, Indramayu. One of the teaching materials taught through the audiolingual method is Ta'diyah Salam or greeting. In the learning process, the teacher uses the Audiolingual method because in this method it is very easy and lightweight in terms of language use and it contains elements of drilling and mimicry, so students easily speak Arabic imitating native speakers.

Through language learning, especially Arabic, each student is expected to be able to know themselves, their culture, and the culture of others, and be able to participate in social life. One culture that is formed in a society is the culture of saying hello as a form 
of respect and appreciation in society. Greetings are words that are often used by everyone in daily activities. When meeting other people, one way to say hello and say hello is to say hello to him. In this paper, the author will elaborate on the implementation of the Audiolingual method in Ta'diyah Salam of the seventh grade students of MTS AlQurani (Al-Qurani Islamic Boarding School), Indramayu, the obstacles faced by teachers in teaching using the audiolingual method, and the efforts made to overcome these obstacles.

\section{THEORETICAL OF STUDY}

Audiolingual method is a method of learning and teaching languages, especially foreign languages. Learning with this method emphasizes the activities of listening, imitating, and reciting sounds of language, such as sentences and dialogue (Qudus and Yusri 2017, 128). Bloomfield in Jufri stated that Audio-Lingual are two words that come from Latin. Audire = listening, and lingua = language. The experts of this method argue that language learning is the formation of a habit (Jufri 2001, 50).

Audiolinguism, which is a term coined by Professor Nelson Brooks in 1964, demands a change in language teaching from an art to a science, which will make it easier for learners to gain mastery of foreign languages effectively and efficiently. Although this method suffered a setback in the late 1960s, audiolingualism and its material based on audio lingual principles are still widely used today (Ramma and Hifni 2015 , 99). Initially, this method was called the Army method. This term is used, because this method is used for the first time in teaching language to American soldiers who will fight after the end of the second world war (Nurbayan 2008, 20). In all its variations and forms of adaptation, the Army Method came to be known as the Audio-Lingual Method (ALM).

ALM relies closely on linguistic and psychological theories. Structural linguists of the 1940s and 1950s were involved in what they called "scientific descriptive analysis" of various languages, and teaching methodologists witnessed the direct implementation of such analysis to the teaching of linguistic patterns. At the same time, behavioristic 
psychologists support models of conditioning learning and habit formation. These models provide the perfect foundation for mimicry drill and patterned exercises which are audiolingual methodologies (Brown 2008, 119).

Audiolingual method is very prioritizing drill (repetition). The method arises because of the time taken to learn the target language. Yet for certain purposes, it is necessary to master language quickly. In audiolingualism that is based on a structural approach, the language taught is poured into pronunciation of words, and the training of sentence patterns intensively many times. The teacher asks students to repeat until there are no mistakes (Ariani and Alamsyah 2009, 10)

The steps usually taken are: a) the presentation of dialogue or short text that the teacher recites repeatedly and the student listens without looking without the text being read, b) the imitation and memorization of the text each sentence simultaneously and the student memorizes it, c) the presentation of the sentence trained with repetition, d) dramatization of dialogue or text that is trained then students demonstrate in front of the class, and e) formation of other sentences in accordance with what is practiced (Ariani, Alamsyah, dkk, 2009: 10).

In the listening learning process that uses the audiolingual method, a teacher can say or play a recorded word or sentence, then students imitate the teacher's words. As for some of the strategies that can be used in applying the audiolingual method, such as (Qudus dan Yusri 2017, 128-129).

1. Dialogue memorization (dialogue memorization), students are given a short dialogue to memorize, then students repeat and present the dialogue.

2. Backward Build up, students are given fragments of sentences, and each student repeats every part of the sentence delivered by the teacher or listened to on a tape, starting with the words at the end of the sentence until the whole series of sentences.

3. Repetition drill, students are emphasized to repeat as loud (sound) as possible what they hear.

4. Chain drill, repetition is done many times by asking students to sit in a circle in the room, then one by one the students ask and answer questions. The teacher 
starts the drill by greeting or asking one of the students. Then the student answers the question, then he asks the friend beside him. The student who was asked then answered and asked the friend next to him, and so on.

5. Single Slot Substitution, the teacher reads and plays a line of dialogue to students, then students say a word or group of words. Students are asked to imitate by correctly entering the word or group of words into the dialogue verse.

6. Multiple Slot Subtitles, this exercise is the same as Single Slot Subtitles, but the scope is wider, not just one verse but one dialog.

7. Question and Answer drill, this model trains students to answer questions correctly.

8. Transformation drill, the teacher gives students a sentence, then students are asked to change the sentence into different forms such as: interrogative, negative, positive, passive, imperative, and so on.

9. Complete the Dialogue, some words in a dialogue are deleted, then students are asked to complete the dialogue.

There are five slogans held by supporters of the Audiolingual Method: a) language is oral (kalam), not written (chitabah), b) language is a set of habits (anzimah min al'adat), c) what must be taught is language (isti'mal al-/ughah), not about language (haula al-lughah), d) language is what is spoken (ma yuqa), not what should be said (ma yanbaghi an-yuqa), and e) those languages vary (mukhtalifah) between one and another (Fakhrurrozi, Mahyudin 2009, 93).

As for the empirical laws regarding learning as the basis of the audiolingual method, are (Sugiani, Siswanto, et al 2017, 69):

1. The basic law of relationships, that is, if two experiences occur together, the appearance of one of them will remind one of the other.

2. The law of practice, that is, the more often the response is put into practice, the stronger the person's memory will have on that.

3. The law of intensity, i.e. the more intensive a response is practiced, the more determined it is learned and the longer it is remembered. 
4. The law of assimilation, which is that every newly aroused condition tends to give rise to the same response that has been caused by the same conditions in the past.

5. The law of influence, i.e. if the response is accompanied or followed by satisfying events, then the response is increasingly strengthened or accepted. Conversely, if a response is accompanied or followed by events that are annoying, then the response is increasingly avoided or not accepted.

The Audiolingual Method is based on at least the following principles (Suyatno 2004, 86).

1. Prioritize speaking and listening skills rather than literacy skills.

2. The ability of language development through habituation formulations.

3. Students practice special patterns of language through structured dialogue and drill until finally an automatic response appears.

4. Structured language patterns are taught using drills repeatedly.

5. Attention and emphasis are given to students who issue free and wrong expressions.

6. This language learning method fits the kinesthetic learning style.

7. Only daily vocabulary and sentences are taught. More concrete vocabulary is taught through demonstrations, objects, and drawings. Abstract vocabulary is taught by combining ideas.

\section{RESEARCH METHODOLOGY}

The problem of producing descriptive data or in other words in this study is attempted on the collection of descriptive data as outlined in the form of reports and descriptions. This type of research can be categorized as a type of descriptive research because descriptive research seeks to describe, describe, or describe systematically and objectively about facts, nature, characteristics, and relationships between elements that exist or a particular phenomenon according to what it is at the time of research done (Suharsimi 2000, 133). 
Data sources in this study were Arabic language teachers and VII grade students of MTS Pondok Pesantren Darussalam Al-Qurani Indramayu, with a total of 10 female students. Data collection techniques are done through interviews, observation, and documentation. At the observation stage, the researcher observed the Arabic learning process on muhadatsah material (ta'diyatus salam) by using the Audiolingual method for Grade VII students of the Islamic Al-Qur'ani Islamic Boarding School in Indramayu. In this case, the researcher becomes a passive observer meaning that the researcher only observes the learning process that takes place without participating in the class.

At the interview stage, researchers conducted interviews with Arabic language teachers to obtain information about the Implementation of Audiolingual Method to VII grade students of the Al-Qur'ani Islamic Boarding School in Indramayu by writing. Besides that, the researcher also interviewed the students to find out their responses after participating in the learning process using the audiolingual method. The documentation relating to the data obtained during the study took place.

\section{RESULT}

In the results of this study, researchers describe three things: 1) how the teacher applies the Audiolingual method in teaching Arabic greeting pronunciation, 2) the obstacles faced by teachers in teaching Arabic greeting pronunciation using the Audiolingual method, and 3) the efforts of the teacher in overcoming these obstacles.

The Implementation of muhadatsah in the seventh grade of MTS Al-Qurani (AlQurani Islamic Boarding School) is held every Monday to Friday at the second hour (07.30-08.30), the third hour (09.00-10.00), and the fourth hour (10.00-11.00) with the different instructors/teachers. In this study, researchers observed muhadatsah learning on ta'diyah as-salam material by using the Audiolingual method for the seventh grade students of Darussalam Islamic Boarding School Al-Qurani Indramayu. While the interviews were conducted with teachers and students conducted via telephone. 


\section{Implementation of Audiolingual Method in Ta'diyah Salam Material for Class VII MTS Students of Islamic Boarding School in Darussalam Al-Qurani Indramayu}

Researchers observed muhadatsah learning on ta'diyah salam material in Grade VII MTS students of the Al-Qurani Islamic Boarding School in Indramayu with the aim to find out the learning model taught by the teacher using the Audiolingual method.

Observations were made on Wednesday, August 12, 2020 at 07.30 a.m in class VII MTS Pondok Pesantren Darussalam Al-Qurani Indramayu. The number of students in class VII is 10 people. The method used in this learning process is the Audiolingual method with the technique of dialogue memorization, backward build up drill, and repetition drill.

At this observation stage, there are three main parts in the learning process of muhadatsah on the ta'diyah salam material by applying the Audiolingual method conducted by the teacher in the class. The three sections cover opening activities, core activities, and closing activities. The researcher will explain the three main sections as follows:

Subjects: Muhadatsah

Teaching Material: Ta'diyah Salam

Method: Audiolingual

Technique: Dialogue memorization, Backward build up, and Repetition drill.

Teacher's name: Marini Tri Cahyani

Class / Semester: VII / I

Day / Date: Wednesday / 12 August 2020

Time: $07.30 \mathrm{am}$

\section{Opening activities}

In the first step in the process of learning muhadatsah on ta'diyah salam with the implementation of the Audiolingual method the teacher does the following activities:

a. The teacher starts the lesson with greetings

b. The teacher asks the lesson to be learned 
c. Before lessons begin, the teacher asks students to pray together and attend students

d. The teacher gives a stimulus by asking students to sing Arabic songs that have been taught before

2. Core activities

In the second step, which is the core activity, the researcher describes the activities or activities in the muhadatsah learning process on the ta'diyah salam with the implementation of the Audiolingual method by the teacher as follows:

a. The teacher starts the Muhadasah lesson by explaining the topic that will be discussed at that time.

b. The teacher writes the topic on the board and explains a little about the meaning of ta'diyah salam and how they are used.

c. The teacher asks students to open their textbooks containing examples of greetings dialogues greetings. Then the teacher reads it with the right expression and intonation while students are asked to pay attention to it. An example of the dialogue is as follows:

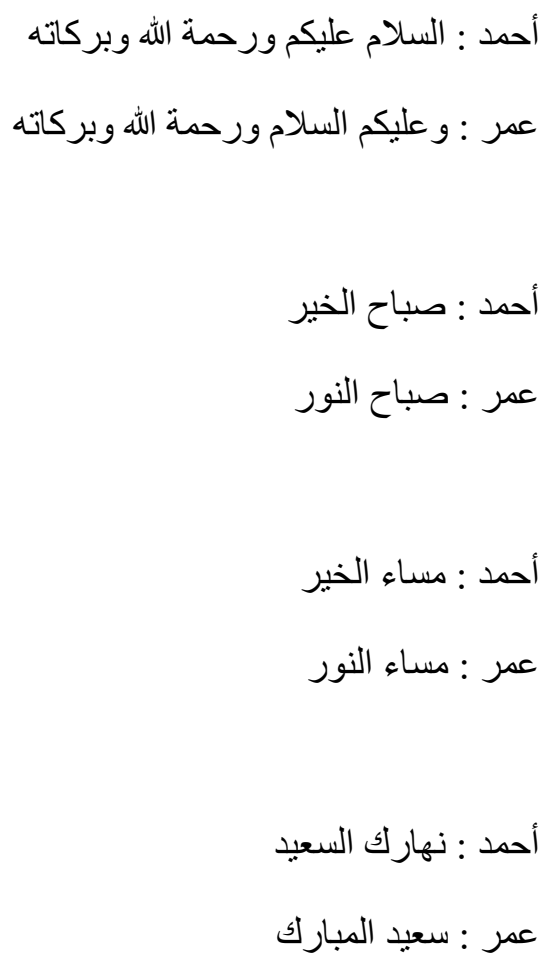


أحمد : لبلتك السعيدة

عمر : سعيدة المباركة

؟أحمد : كيف حاللك

عمر : الحمد الله، بخير و العافية

أحمد : أهلا وسهلا

عمر : أهلا بك

أحمد : أهلا

عمر : مرحبا

أحمد : شكرا

عمر : عفو

d. The teacher repeats to read the short dialogue and asks all students to follow it e. The teacher tries to say greetings that have been read and students who answer them

f. The teacher asks two students to read the dialogue in front of the class

g. The teacher repeats to read the short dialogue and asks all students to follow it in a loud voice

h. The teacher asks students to memorize the short dialogue and look for friends who will be the interlocutors in the conversation

i. The teacher asks students in turn to come forward and practice the dialogue.

j. When students appear to practice the dialogue, the teacher also checks and corrects wrong readings and intonations from students, so they can express the contents of the dialogue correctly and smoothly.

$\mathrm{k}$. The teacher gives rewards to students who successfully engage in dialogue well. 


\section{Closing activities}

The last activity that the teacher does is the closing activity which contains a series of activities as follows:

a. The teacher concludes the contents of the material taught at that time

b. The teacher divides students into two groups to re-practice the dialogue examples in the textbook

c. The teacher asks students to be serious when practicing the dialogue

d. The teacher asks students together once again to read the example of the dialogue

e. The teacher motivates students to keep their enthusiasm for learning and not give up in mastering good Arabic

f. The teacher closes the lesson with a prayer and ends with a greeting

From the results of these observations, the researchers found that the students were very enthusiastic in participating in the muhadasah-themed ta'diyah salam especially when learning using dialogue memorization techniques. The students were very enthusiastic to try to practice the conversation about ta'diyah salam in front of the class. The students were happy when they performed with their partners practicing the dialogue using Arabic. They scramble to try to practice the dialogue in front of the class, not even just in front of the class, they also practice it outside the classroom during breaks and outside class hours because in general, they have memorized it. The students were very happy to be able to have a conversation that began with greetings in Arabic, even though they were asked to memorize them. By repeating many times by the teacher who is then followed by students, making students memorize faster and making students become accustomed to their pronunciation. 


\section{Obstacles that Teachers Meet in Teaching Muhadatsah on Ta'diyah Salam Using the Audiolingual Method}

Teaching ta'diyah salam material by using the Audiolingual method in the beginner class is certainly not easy. There are several obstacles that teachers find in the learning process. From the results of interviews conducted by the Arabic language teachers (muhadatsah) in class VII MTS Darussalam Islamic Boarding School Al-Qurani Indramayu, there are several obstacles found during the learning process, including "time".

"So, the perceived obstacle in using audiolingual methods is time. Because, first we have to get the child accustomed to hearing, so the repetition happens repeatedly and then they practice until they memorize. And it takes a long time, because it could be that the mufrodat they met at that time was indeed a new mufrodat, so directing towards direct practice and memorization is difficult (Interview with Arabic teacher on Thursday, 13 August 2020 at 10.00 am)."

In addition, the obstacle found by the teacher is "the condition of students who are not familiar with Arabic". Since the seventh grade class of MTS is a beginner class in the Marhawi Tsanawiyah who accepts Arabic learning, some students still feel a little strange and a little difficult to directly imitate the correct Arabic pronunciation.

"Because $30 \%$ of students are new to Arabic, so they have a little difficulty if they directly imitate and pronounce Arabic texts directly (Interview with Arabic teacher on Thursday, 13 August 2020 at 10.15 am)."

The last obstacle is "feeling tired and bored". Because the Audiolingual method strongly emphasizes drill or repetition that is carried out continuously, students finally feel bored and bored and feel tired because they have to keep repeating and need enough energy to continue to follow the learning to the end.

"By using the Audiolingual method and students imitating continuously from the start, they will feel tired and bored and make them less enthusiastic in learning (Interview with Arabic teacher on Thursday, 13 August 2020 at 10.20 am)." 


\section{The Efforts the Teacher Made in Overcoming Obstacles Encountered During the Learning Process Using the Audiolingual Method}

Every teacher in teaching must find obstacles in the teaching process. Many obstacles faced by teachers, of course, are very different. As for how many obstacles are encountered by the teacher, there must be a way out to overcome these obstacles. In the results of this study, the researcher also explained the efforts made by the teacher in overcoming the obstacles encountered in the process of learning ta'diyah salam to students of VII MTS class Pondok Pesantrean Darussalam AI-Qurani Indramayu. These efforts include:

1. The teacher must tell students about the material to be taught tomorrow so that they are more prepared in accepting the lesson and the teacher must be as clever as possible to arrange the time that will be used in the learning process.

"Efforts that must be made are regarding timing. In later learning, we must give the children tomorrow's lesson. So, familiarize children to know what they will learn next. Because, when they find out, we hope that what they hear at the next meeting is nothing new. And we have to know every child's ability so that we know how many minutes it takes and they can mimic how many minutes and can memorize how many minutes, so the important thing is timing (Interview with Arabic teacher on Thursday, 13 August 2020 at 10.35 am). "

2. The teacher must convey the text of the Arabic conversation as clearly as possible to students and must not be in a hurry so that students can receive and catch the correct pronunciation of the sentence.

"The instructor must be really clear and slow in reciting Arabic sentences or texts so that students who are new to Arabic can receive the lessons delivered (Interview with Arabic teacher on Thursday, 13 August 2020 at 10.40 am)."

3. Teachers must be as clever as possible using the methods and media of learning to students who are taught, so that they do not feel bored and tired and can participate in learning with enthusiasm to the end.

"Teachers don't just use audiolinguals, but integrate them with other language games so they don't feel bored (Interview with Arabic teacher on Thursday, 13 August 2020 at $10.50 \mathrm{am})$." 
Based on the results of the research described above, the IMPLEMENTATION of the Audiolingual method in learning muhadatsah on ta'diyah salam material can be applied to students of class VII MTS Darussalam Islamic Boarding School Al-Qurani Indramayu. With this method, students can mimic and recite greetings in Arabic that are correct in accordance with what the teacher teaches based on the applied drilling system.

\section{CONCLUSION}

From the results of the research and discussion that have been obtained by researchers, it can be concluded that there are three main activities carried out by the teacher in applying the Audiolingual method. These activities include opening activities, core activities, and closing activities. The techniques used by teachers in teaching ta'diyah salam include memorization dialogs, backward build ups, and repetition drills.

There are several obstacles in the learning process encountered by the teaching teacher including: limited time available with a well-organized drilling system, the condition of students who are not familiar with Arabic, as well as the fatigue and boredom experienced by students when learning takes place. However, of the many obstacles encountered, the teacher continues to strive to be able to overcome these obstacles by organizing the best possible time so that learning can run well, conveying conversation texts as clearly as possible to students, and providing learning media that are interesting for students so that they don't get bored quickly and are tired.

\section{REFERENCES}

Arikunto, Suharsimi. 2000. Manajemen Penelitian. Jakarta: PT. Rineka Cipta.

Brown, Douglas. 2008. Prinsip Pembelajaran dan Pengajaran Bahasa. Jakarta: Person Education.

Fakhrurrozi, Aziz dan Erta Mahyudin. 2009. Pembelajaran Bahasa Arab. Jakarta: Direktorat Jenderal Pendidikan Islam Kementerian Agama.

Hanani, Nurul. 2016. "Efektivitas Penggunaan Metode Audiolingual dalam Pembelajaran Bahasa Arab". Realita: Jurnal Penelitian dan Kebudayaan Islam 14, No. 2. 
Jufri, Jufri. 2001. Prinsip-Prinsip Strategi Pembelajaran Bahasa. Makassar: SUM Press.

Kumaravadivelu, B. 2006. Understanding Languange Teaching: From Method to Postmethod. London: Lawrence Erlbaum Associates.

Madusari, Endah Ariani, Teuku Alamsyah, dkk. 2009. Metodologi Pembelajaran. Jakarta: Departemen Pendidikan Nasional.

Maspalah, Maspalah. 2015. Metode Audiolingual dalam Pembelajaran Bahasa Arab Untuk Meningkatkan Kemampuan Berbicara. Jurnal Pendidikan Bahasa dan Sastra 15, No. 1: 68-78. https://doi.org/10.17509/bs jpbsp.v15i1.800

Nurbayan, Yayan. 2008. Metodologi Pembelajaran Bahasa Arab. Bandung: Zein Al-Bayan.

Purwanto, M. Ngalim. 2000. Ilmu Pendidikan Teoritis dan Praktis. Bandung: Remaja Rosda Karya.

Qudus, Muhammad dan Yusri. 2017. "Keefektifan Penggunaan Metode Audiolingual Dalam Pembelajaran Kemampuan Menyimak Bahasa Jeman". Indonesian Journal of Educational Studies 20, No. 2. https://doi.org/10.26858/ijes.v20i2.4823

Ramma, Kammil dan Ahmad Hifni. 2015. Pengantar Metodologi Pembelajaran Bahasa Arab. Kalimantan Selatan: IAIN Antasari Press.

Rikabi, Jaudat. 1996. Turuqu Tadris Al-Lughah Al-'Arabiyah. Damaskus: Dar al-Fikr.

Sugiani, Yani, Siswanto, dkk,. 2017. "Pengenalan Jenis Sayuran dalam Bahasa Inggris Berbasis Android Menggunakan Metode Audiolingual,." Seminar Nasional Riset Terapan.

Suyatno, Suyatno. 2004. Teknik Pembelajaran Bahasa dan Sastra; Berdasarkan Kurikulum Berbasis Kompetensi. Surabaya: Penerbit SIC.

Zaenuddin, Radliyah, dkk. 2005. Metodologi Dan Strategi Alternatif Pembelajaran Bahasa Arab. Yogyakarta: Pustaka Rihlah Group. 